\title{
Peltogyne barbata (Leguminosae, Detarioideae), a new species endemic to the Trombetas River area, Brazil
}

\author{
Fabio Júnior Kochanovski ${ }^{1}$ (D) Ângela Lúcia Bagnatori Sartori ${ }^{2}$ \& Vidal de Freitas Mansano ${ }^{3}$
}

Summary. Peltogyne barbata (Leguminosae, Detarioideae), a new species endemic to lake margins and the banks of the Trombetas River in the state of Pará, northern Brazil, is described and illustrated. The new species is morphologically similar to $P$. densiflora Spruce ex Benth. in fruit shape and flower morphology, and both species occur in flooded areas (igapó). Peltogyne barbata can be distinguished by its partially tomentose ovary, the coloration of its adaxial sepals, and for having leaves present near the inflorescences pre-anthesis but branches without leaves post-anthesis. We provide an identification key to the species of the genus Peltogyne that occur in the Trombetas River region, as well as a line drawing, a distribution map and colour photographs of the new species in its native environment.

Key Words. Aphyllous, bauxite, Fabaceae, northern Brazil, ovary.

\section{Introduction}

Peltogyne Vogel is currently the most speciose genus of the Hymenaea clade, subfamily Detarioideae (Leguminosae). The genus comprises 23 species (Silva 1976) and is considered to be monophyletic (Bruneau et al. 2008; Fougère-Danezan et al. 2007; Legume Phylogeny Working Group 2017). Species of the genus Peltogyne are known locally as "purple-heart" or "pau-roxo" because of the colouring of the heartwood, which ranges from purple to red. They are trees up to $40 \mathrm{~m}$ tall with trunks up to $1.5 \mathrm{~m}$ in diameter (Silva 1976). The wood has great economic value for its beauty and because of the resistance of its dry timber to attack by fungi and termites (Ducke 1938). It is used in the production of fine decorative objects (Record \& Hess 1943). Peltogyne has a large neotropical distribution, occurring from Mexico to the southeastern region of Brazil with a centre of diversity in the lowland tropical rainforests (Ducke 1938; Silva 1976; Mackinder 2005). Some species are narrow endemics; for example, $P$. gracilipes Ducke is restricted to Maracá Island in Roraima and $P$. chrysopis Barneby to southern Bahia. New collections have resulted in the discovery of several new species (Barneby 1994; Fernandes 1994), and a revision of the genus is currently underway (Kochanovski et al., unpublished data). The new species presented here was previously mistakenly identified as $P$. densiflora Spruce ex Benth., an understandable error given the similarity in fruit and inflorescence presentation. Nevertheless, the arrangement of the leaves and the inflorescence branching, as well as the unique arrangement of the ovary trichomes, demonstrate a number of differences between the two species. The discovery of this new species fills in some of the collecting gaps in the Amazon region and adds to our knowledge of the Amazonian flora (Nelson et al. 1990).

\section{Material and Methods}

For this study, the following herbaria were consulted: INPA, HSTM, UEC, and RB. High-definition photographs from the NY herbarium were also analysed as complementary material. The terminology used in the species description is adapted from Simpson (2006) and from Harris \& Harris (1994). Field collecting trips provided additional information about ecology, growth form, fruit dispersal and geographical distribution. A top set of the newly collected specimens is deposited in the UEC herbarium, and duplicates have been sent to the RB, NY and CGMS herbaria.

\section{Taxonomic Treatment}

Peltogyne barbata Kochan. E M Mansano sp. nov. Type: Brazil, Pará state, Oriximiná, Porto Trombetas, Macaxeira Lake, 7 July 1980, G. M. Martinelli 7280 (holotype: RB!; isotypes: HUEFS, INPA!, K, MBM, MG!, MO, NY, SPF, UEC!).

http://www.ipni.org/urn:lsid:ipni.org:names:77202827-1

Tree or shrub $3-5$ (- 13) m tall, bark dark grey, branches with lenticels and exfoliating. Stipules cadu-

Accepted for publication 7 January 2020. Published online 29 April 2020

1 Universidade Estadual de Campinas, Instituto de Biologia, Departamento de Biologia Vegetal, Programa de Pós-Graduação em Biologia Vegetal, Rua Monteiro Lobato, 255, CEP 13083-862, Cidade Universitária Zeferino Vaz, Campinas, SP, Brazil. e-mail: prefiroasdaninhas@gmail.com

2 Universidade Federal de Mato Grosso do Sul, Instituto de Biociências, Avenida Senador Felinto Muller, S/N, CEP 79070-900, Cidade Universitária, Mato Grosso do Sul, Brazil.

3 Instituto de Pesquisas do Jardim Botânico do Rio de Janeiro, DIPEQ, Rua Pacheco Leão, 915, CEP 22460-030, Jardim Botânico, Rio de Janeiro, RJ, Brazil. 
cous. Leaves alternate, distichous, bifoliolate, leaflets elliptic to lanceolate, $9.3-11 \times 3.6-5 \mathrm{~cm}$, base rounded, apex acute, margin entire, discolorous, adaxial face glabrous and shiny, petiole terete, 2 $2.5 \mathrm{~cm}$ long, petiolule $4-5 \mathrm{~mm}$, primary vein embedded on the adaxial face, paler in colour than the blade, prominent secondary veins on both faces, pellucid glands visible. Inflorescence a terminal corymb, $11-18 \mathrm{~cm}$ long, flowers concentrated at the apex of long thin branches with few leaves (in pre-anthesis), rachis pubescent. Flowers with pedicel 3-4 mm long, bracteoles bright green, glabrous except for some sparse trichomes persistent until the intermediate stage (sometimes until pre-anthesis). Buds prolate, hypanthium inflated, $4-5 \mathrm{~mm}$ in length and $3-$ $4 \mathrm{~mm}$ in width, light green. Calyx tetramerous, sepals brown, tomentose on both sides, adaxial face margin glabrous and purple, as for the petals. Corolla pentamerous, petals membranaceous, spatulate, purple, with a cream-coloured base, secondary veins parallel to the primary veins, pellucid glands present on both surfaces. Stamens 10, filaments white, erect, 22 - $24 \mathrm{~mm}$ long, exserted, anthers dorsifixed, versatile. Gynoecium light green, stipe $2 \mathrm{~mm}$ long, terete in cross section, glabrous. Ovary obovate, tomentose, glabrous in the region of the ovary cleft, $4-5 \mathrm{~mm}$ long and $2-3 \mathrm{~mm}$ wide. Style terminally inserted on the ovary, $10-24 \mathrm{~mm}$ long, glabrous. Stigma terminal, peltate, glandular, with a cleft on the adaxial face. Ovules $5-6$, inserted in the region of carpellary cleft. Fruit a samaroid, laterally compressed, subtriangular, winged, indehiscent, $2.5-2.8 \times 2.2-2.5$ $\mathrm{cm}$, with pedunculated insertion, hairy, resin pockets on surface, protruding ribs, mesocarp farinaceous (powdery). Seed pendulous, one per fruit, oblong, smooth, $12-14 \times 9-11 \mathrm{~mm}$, aril lacking. Fig. 1 .

RECOGNItION. Peltogyne barbata is similar to P. densiflora mainly in the shape of its marginally winged fruit, its elliptic-lanceolate leaflets with raised venation, its prolate flower bud, and its inflated hypanthium, as well as in the overlapping geographical distribution of the two species. However, P. barbata differs by being a $13 \mathrm{~m}$ tree (vs up to $15-20 \mathrm{~m}$ in $P$. densiflora) with a grey trunk (vs brown and slender branches in $P$. densiflora), an ovary that is mostly tomentose but glabrous on the carpel cleft region (vs an entirely tomentose ovary in $P$. densiflora), an inflorescence with up to 30 flowers (vs more than 50 flowers in $P$. densiflora), and the adaxial face of the sepal of the same purple colour as the petals (Fig. 2A) (vs. adaxial sepals cream-coloured in $P$. densiflora). Peltogyne densiflora differs in having brown bark and thicker branches, a tomentose ovary and a cream-coloured adaxial face of the sepal. In addition, the fruits of $P$. barbata have a subtriangular shape (Fig. 2B), whereas they are orbicular in $P$. densiflora. Young fertile branches of $P$. barbata have leaves (Fig. 2C), but the branches become aphyllous when the inflorescences are mature (Fig. 2D). Peltogyne densiflora and $P$. barbata have similar structures of inflorescence subunits; however, in $P$. densiflora, the inflorescences have open flowers that are attached to a long aphyllous branch $(16-25 \mathrm{~cm}$ long) that supports the inflorescence (Fig. 2E), whereas those in P. barbata have a short aphyllous branch $(0-5 \mathrm{~cm}$ long).

DISTRIBUTION. This species is endemic to the municipality of Oriximiná, Pará state, Brazil. It is found along the banks of the Trombetas River and nearby lakes. Map 1.

SPECIMENS EXAMINED. BRAZIL. Pará: Oriximiná, Distr. of Porto Trombetas, Basin of Rio Trombetas, $20 \mathrm{~km}$ up Rio Mapueira from Cachoeira Porteira on E bank, 31 May 1974, D. G. Campbell P22410 (INPA); 4 km S of Cachoeira Porteira, 6 June 1974, D. G. Campbell P22527 (INPA!, NY); Erepecú Lake, Reserva Biológica do IBDF, 10 July 1980, G. M. Martinelli 7372 (HUEFS, INPA!, NY, UEC!); Erepecú Lake, ao longo do lago [along the lake], 16 July 1980, C. A. C. Ferreira 1530 (INPA!, MO, NY, US); Rio Trombetas, Rio Trombetas, margem esquerda do lago [left bank of the lake] Erepecú, ao longo do lago [along the lake], 16 July 1980, C. A. C. Ferreira et al. 1530 (INPA! NY, US); Batata Lake, N of Porto Trombetas, 24 July 1980, C. A. C. Ferreira 1781 (INPA!, NY, US); Batata Lake, area flooded by bauxite, near the Igarapé Caranã, 7 Aug. 1986, E. Soares 182 (INPA); near Porteira Falls, margin of Tapagem Lake, 23 Aug. 1986, C. A. C. Ferreira 8008 (INPA! MIRR, MO, NY, US); Lago do Batata, próximo ao [near] Igarapé do Caranã. Mata de igapó, área invadida pela bauxita [area invaded by bauxite], 7 Aug. 1986, E. Soares HSTM6134 (HSTM!); Mineração Rio do Norte, Lago do Batata. Floresta de Igapó, 12 June 1989, E. Soares, HSTM6137 (HSTM!); Cachoeira da Porteira, entrada [entrance], 27 May 1999, S. M. Faria 1721 (HSTM!); Cachoeira da Porteira, estrada [entrance], 27 May 1999, S. M. Faria 1722 (HSTM!); Rio Mapuera, Três Ilhas. Campina, solo arenoso, 27 May 1999, H. C. Lima 5661 (HSTM!); Rio Mapuera, três ilhas [three islands], 27 May 1999, H. C. Lima 5662 (HSTM!); Porto Trombetas, margin Faro R., 14 Nov. 2000, S. M. Faria 2131 (HSTM); Porto Trombetas, Serra do Matio, 24 Aug. 2001, S. M. Faria 2160 (HSTM); Batata Lake, Porto Trombetas, 2 June 2017, F. J. Kochanowski et al. 738 (NY, RB, UEC!); near to Moura Lake, 4 June 2017, F. J. Kochanovski et al. 740 (NY, RB, UEC!); Lago Batata, Porto Trombetas, 4 June 2017, F. J. Kochanovski et al. 740 (UEC!).

HABITAT. Riparian forests, especially along the river banks, apparently in soils that are rich in bauxite. Found in areas around $90 \mathrm{~m}$ elevation.

CONSERVATION STATUS. This species can be classified as Endangered (EN), based on GeoCAT (Bachman et al. 2011; IUCN Standards and Petitions Subcommittee 2017) 

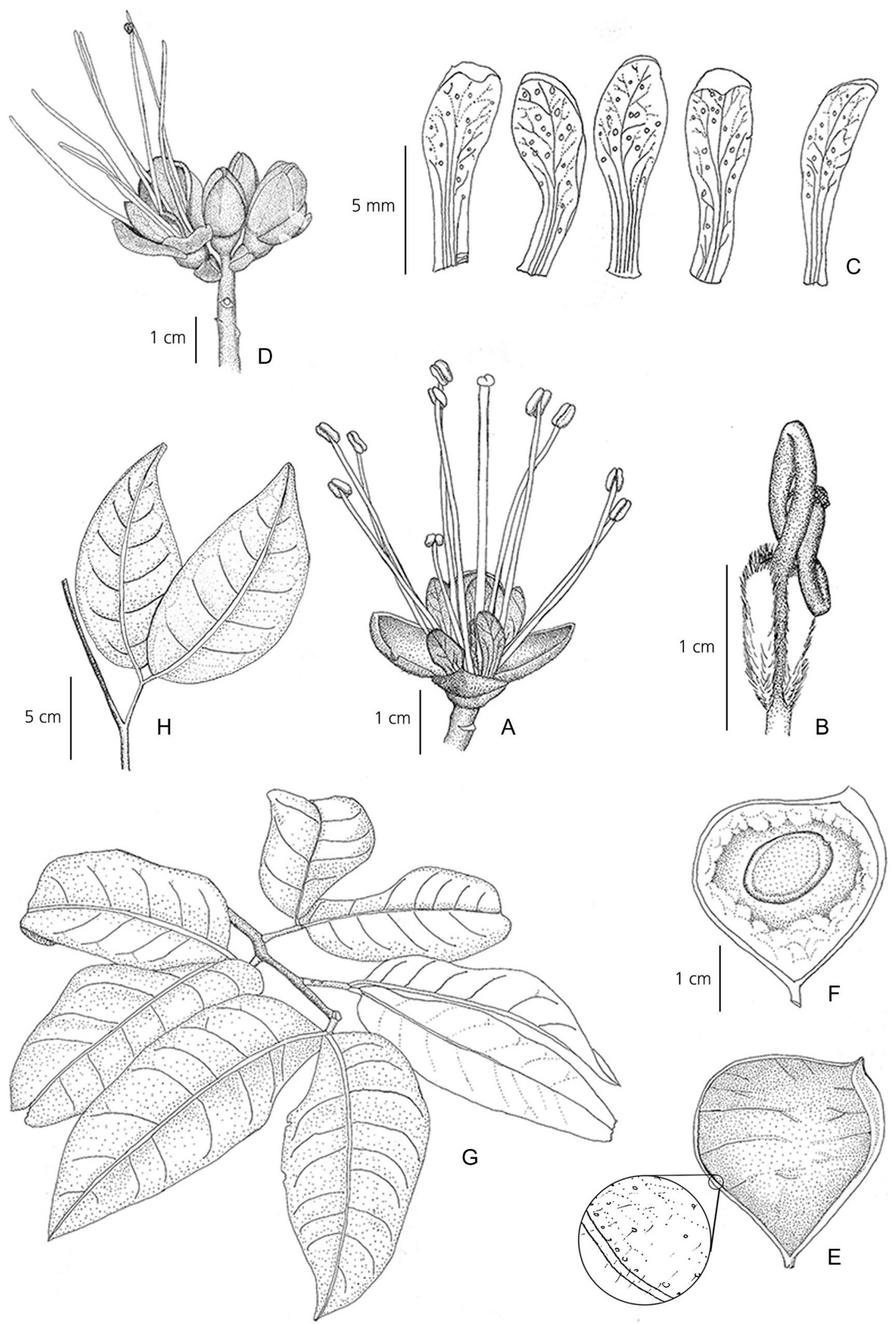

Fig. 1. Peltogyne barbata. A flower at anthesis; B tomentose ovary, with adaxial face glabrous; C petals; D part of an inflorescence; $\mathrm{E}$ indehiscent fruit, detail of pilosity and resin bags; $\mathrm{F}$ opened fruit showing seed; $\mathrm{G}$ bifoliolate leaves; $\mathrm{H}$ leaves. From $\mathrm{F}$. $J$. Kochanovski 740 (UEC). DRAWN BY FABIO J. KOCHANOVSKI. 

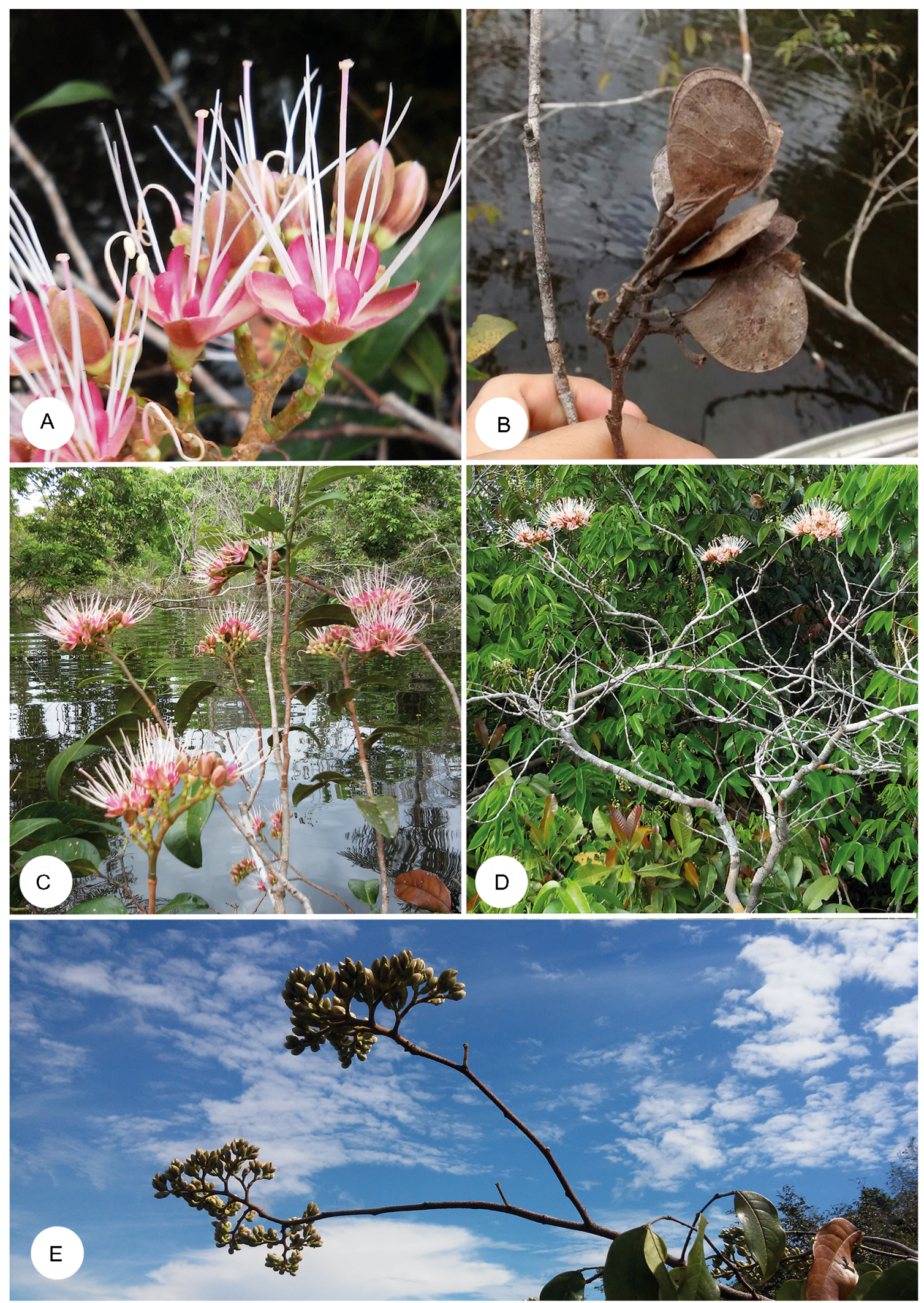

Fig. 2. Peltogyne barbata. A flowers with purple sepals, like petals; $\mathrm{B}$ subtriangular fruits; $\mathrm{C}$ branches with foliage and inflorescences; D leafless branches post-anthesis, E P. densiflora, inflorescence on an aphyllous branch. 


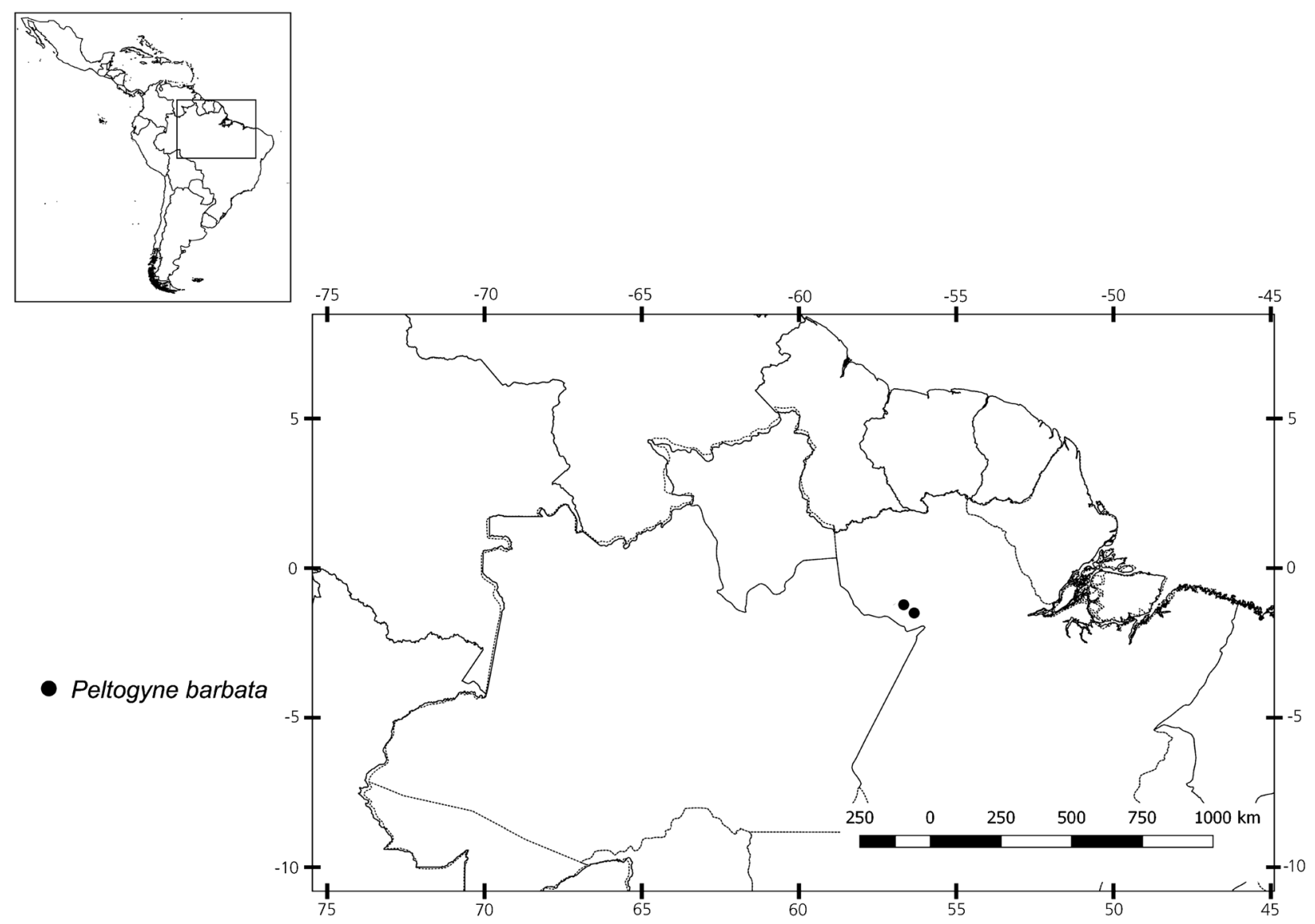

Map 1. Geographical distribution of Peltogyne barbata in the Amazon.

because it has an extent of occurrence (EOO) of 266,903 $\mathrm{km}^{2}$ and an area of occurrence (AOO) of 16,000 $\mathrm{km}^{2}$. It occurs only in localities close to the Trombetas River. Some of these areas are being mined for bauxite, and all of the endemic species in the area are threatened.
PHENOLOGY. Flowering in June and July, fruiting in August.

ETYMOLOGY. The epithet barbata is Latin for "bearded" and refers to the indumentum of the ovary.

VERNACULAR NAME. Pau roxo (Portuguese).

\section{Identification key for the species of Peltogyne in the Trombetas River area}

1a. Fruit dehiscent; bud and hypanthium inflated $\ldots \ldots \ldots \ldots \ldots \ldots \ldots$. . . . . . . . Paniculata

1b. Fruit indehiscent; bud prolate; hypanthium not inflated $\ldots \ldots \ldots \ldots \ldots$

2a. Petals linear (oblanceolate); bracteoles persistent; fruit sessile, pubescent . . . . . . . . . . P. campestris

2b. Petals spatulate; bracteoles caducous; fruit stipitate, glabrous $\ldots \ldots \ldots \ldots \ldots$

3a. Tree 15 - $20 \mathrm{~m}$ tall; trunk tortuous; inflorescence many-flowered (more than 50 flowers per inflorescence); inflorescence attached to a long aphyllous branch $(16-25 \mathrm{~cm})$; adaxial sepals cream-coloured; ovary entirely pubescent; bud elongate, hypanthium showy; fruit orbicular . . . . . . . . . . . . . . . P. densiflora

3b. Shrub to small tree, to $13 \mathrm{~m}$ tall; trunk not tortuous; inflorescence few-flowered (up to 30 per inflorescence); inflorescence attached to a short aphyllous branch $(0-5 \mathrm{~cm})$; adaxial sepals purple; ovary partially pubescent, glabrous in the carpel cleft; fruit subtriangular $\ldots \ldots \ldots \ldots \ldots \ldots \ldots \ldots \ldots \ldots$

\section{Acknowledgements}

We thank the curators of the following herbaria for access to their collections: HSTM, INPA, RB and UEC. We also express our gratitude to geologist Cintria Neves Nunes, to the fieldwork assistants and guides in the Porto Trombetas region, and to Dr Flavio Macedo
Alves. We thank the following organisations for their financial support: CAPES (for a doctoral scholarship to the first author), NSF (award number 1456232), FAPERJ (E-26/2003.007/2017) and CNPq (301550/ 2015-8). The English text was revised by Dewey Litwiller. 
Open Access This article is licensed under a Creative Commons Attribution 4.0 International License, which permits use, sharing, adaptation, distribution and reproduction in any medium or format, as long as you give appropriate credit to the original author(s) and the source, provide a link to the Creative Commons licence, and indicate if changes were made. The images or other third party material in this article are included in the article's Creative Commons licence, unless indicated otherwise in a credit line to the material. If material is not included in the article's Creative Commons licence and your intended use is not permitted by statutory regulation or exceeds the permitted use, you will need to obtain permission directly from the copyright holder. To view a copy of this licence, visit http://creativecommons.org/ licenses/by/4.0/.

\section{References}

Bachman, S., Moat, J., Hill, A., de la Torre, J. \& Scott, B. (2011). Supporting Red List threat assessments with GeoCAT: geospatial conservation assessment tool. Zookeys 150: 117 - 126.

Barneby, R. C. (1994). A new purpleheart (Peltogyne, Caesalpiniaceae) from South Bahian Atlantic Forest (Brazil). Brittonia 46(4): 270 - 272.

Bruneau, A., Mercure, M., Lewis, G. P. \& Herendeen, P. S. (2008). Phylogenetic patterns and diversification in the caesalpinioid legumes. Botany 86: 697 - 718.

Ducke, A. (1938). Notes on the purpleheart trees (Peltogyne Vog.) of Brazilian Amazonia. Tropical Woods 54: 1 - 7.

Fernandes, A. (1994). Novitates florae nordestinae brasiliensis. Bradea 6(33): 280.

Fougère-Danezan, M., Maumont, S. \& Bruneau, A. (2007). Relationships among resin producing
Detarieae s.l. (Leguminosae) as inferred by molecular data. Syst. Bot. 32(4): 748 - 761.

Harris, J. G. \& Harris, M. W. (1994). Plant Identification Terminology: an Illustrated Glossary, pp. 140 - 216. Spring Lake Publishing, Spring Lake, Utah.

IUCN Standards and Petitions Subcommittee (2017). Guidelines for Using the IUCN Red List Categories and Criteria, Version 13. Prepared by the IUCN Species Survival Commission. IUCN Council, Gland \& Cambridge http://www.iucnredlist.org/documents/RedListGuidelines.pdf.

Mackinder, B. (2005). Peltogyne, Detarioideae. In: G. P. Lewis, B. Schrire, B. Mackinder \& M. Lock (eds), Legumes of the World. Royal Botanic Gardens, Kew.

Nelson, W. B., Ferreira, C. A. C., Silva, M. F. \& Kawasaki, M. L. (1990). Endemism centres, refugia and botanical collection density in Brazilian Amazonia. Nature 345(6277): $714-716$.

Record, S. J. \& Hess, R. W. (1943). Timbers of the New World, pp. 303 - 305. Yale University Press, New Haven, Connecticut.

Silva, M. F. (1976). Revisão taxonômica do gênero Peltogyne Vog. (Leguminosae - Caesalpinioideae). Acta Amazon. 6(1): 1 - 61.

Simpson, M. G. (2006). Plant Systematics, pp. 347 - 407. Academic Press, San Diego, California.

The Legume Phylogeny Working Group (LPWG) (2017). A new subfamily classification of the Leguminosae based on a taxonomically comprehensive phylogeny. Taxon 66: $44-77$.

\section{Publisher's Note}

Springer Nature remains neutral with regard to jurisdictional claims in published maps and institutional affiliations. 